\title{
An inventory and morphometric analysis of British Columbia glaciers, Canada
}

\author{
Erik SCHIEFER, Brian MENOUNOS, Roger WHEATE
}

\begin{abstract}
National Resources and Environmental Studies Institute and Geography Program, University of Northern British Columbia, 3333 University Way, Prince George, British Columbia V2N 4Z9, Canada

E-mail: schiefer@geog.ubc.ca
\end{abstract}

\begin{abstract}
We describe an automated method to generate an inventory of glaciers and glacier morphometry from a digital topographic database containing glacier boundaries and a digital elevation model for British Columbia, Canada. The inventory contains over 12000 glaciers with a total cumulative area that exceeds $25000 \mathrm{~km}^{2}$, based on mapping from aerial photographs circa the mid-1980s. We use the inventory to examine dimensional characteristics among glaciers, namely the scaling relations between glacier length, width and area. Glacier length is a good predictor of glacier area, and its predictive ability improves when glaciers are stratified by the number of up-valley accumulation basins. The spatial pattern of glacier mid-range altitude parallels glaciation limits previously mapped for British Columbia and similarly reflects large-scale controls of orographic precipitation and continentality. The inventory is also used to refine models that relate glacier mid-range and terminus altitudes to regional position, aspect and, in the case of terminus altitudes, an index of glacier shape. Relations between glacier altitude limits and controlling spatial and topographic factors are used to make further climatic and mass-balance inferences from the glacier inventory.
\end{abstract}

\section{INTRODUCTION}

Glaciers in the western Canadian province of British Columbia represent about $23 \%$ and $4 \%$ of the total conterminous North American and global non-polar glacier cover, respectively (Williams and Ferrigno, 2002), with an estimated extent of $28800 \mathrm{~km}^{2}$ during the mid-1980s (Schiefer and others, 2007). Melt from recent glacier retreat in British Columbia supplements snowmelt runoff required for humans and aquatic ecosystems (Barnett and others, 2005; Stahl and Moore, 2006), contributes significantly to contemporary sea-level rise (Schiefer and others, 2007) and increases the risk posed by landslides and outburst floods (Clague and Evans, 2000; Holm and others, 2004). Despite their importance, glaciers in western Canada are inadequately represented in current glacier inventories.

Glacier inventories can facilitate land-use planning and the choice of sensible morphometric parameters for monitoring glacier change (Dyurgerov and Bahr, 1999; Barry, 2006; Hoelzle and others, 2007; Raup and others, 2007). Historical glacier lengths, for example, which can often be measured from dated maps, photography or end moraine positions, can be related to past glacier areas or volumes with established scaling relations (e.g. Oerlemans and others, 2007). Glaciers are one of the best natural indicators of climate (Lemke and others, 2007), and changes in glacier length are widely recognized as reliable and easily observed evidence of climate change (Lemke and others, 2007; Paul and others, 2007). Inventory data may also be used to derive characteristic glacier dimensions and scaling relations for parameterizing time-response models (e.g. Nye, 1965; Paterson, 1972; Jóhannesson and others, 1989; Bahr and others, 1997). Glacier-inventory data have additionally been used to explore altitude-aspect relations which provide a background for making climatic inferences from past and present glacier distributions (Evans and Cox, 2005; Evans, 2006).
The first substantial mapping of western cordillera glaciers in Canada resulted from the Alberta-British Columbia Interprovincial Boundary Commission in the 1920s, covering the Rocky Mountains from the US border to $54^{\circ} \mathrm{N}$ at a nominal scale of $1: 62500$ (100 ft contours). Federal topographic mapping at 1:50000 (100 ft contours), was pursued after 1945, but not completed for British Columbia until four decades later. The International Hydrologic Decade 196575 generated new interest in glacier-inventory and massbalance studies, best summarized by Ommanney (2002); however, these were not comprehensive at a large scale. A Canadian Glacier Inventory was initiated in 1968 with the goal of developing a complete national database of glaciers (Ommanney, 1971); however, outside the Canadian Arctic, only the glaciers of Vancouver Island and the Stikine River basin were inventoried and subsequently submitted to the World Glacier Inventory (WGI) by 1988 (Haeberli and others, 1989). The only subsequent additions of Canadian glaciers to the WGI were for the Yukon Territory and neighboring St Elias Mountains in northwestern British Columbia (US National Snow and Ice Data Center, http://nsidc.org/ data/docs/noaa/g01130_glacier_inventory). These inventories aimed to be regionally comprehensive, with glaciers being mapped directly from aerial photographs circa the 1950s and 1960s. Topography of British Columbia was completely mapped at 1:20000 under the provincial Terrain Resource Inventory Management (TRIM) program (Geographic Data BC, http://ilmbwww.gov.bc.ca/bmgs/pba/ trim). Air-photograph interpreters mapped physiographic features with $20 \mathrm{~m}$ contours and established a provincial digital elevation model (DEM), from late-summer photography obtained during the 1980s. This program included the digital mapping of glacier and icefield extent, but without individual flowshed delineation.

Building on the TRIM digital database, we present an automated method for extracting individual glacier extents, altitude distributions and dimensional characteristics for 


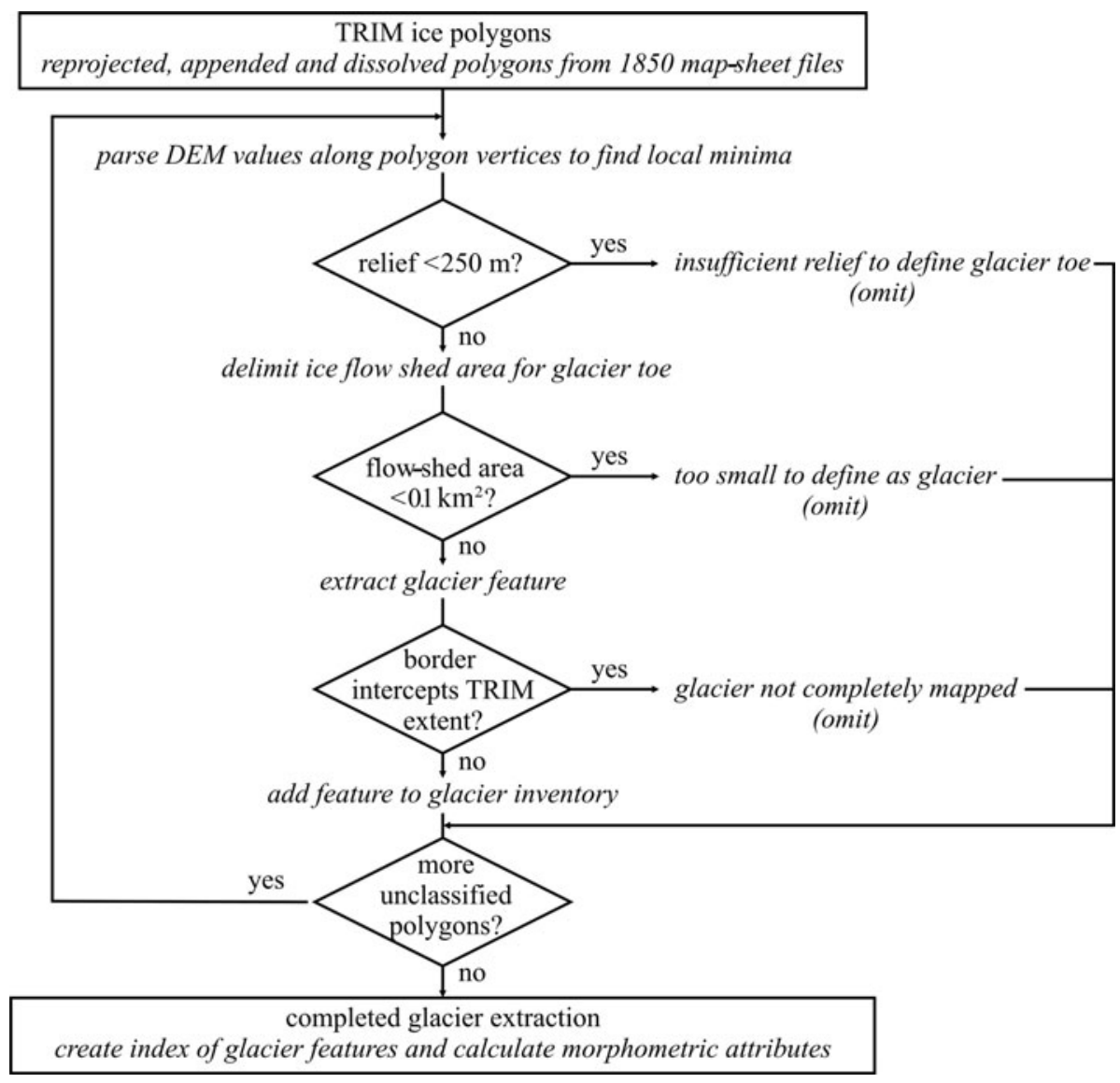

Fig. 1. Algorithm used to extract glacier features from the TRIM ice polygon mapping.

most glaciers in British Columbia. Measured parameters include glacier area, length, width, shape, aspect, altitude range and hypsometry. In particular, we examine how glacier length co-varies with these other measured variables. Spatial variability of glacier altitudes is interpolated for all of glacierized British Columbia and associated with large-scale topographic controls. The size and consistency of this new glacier database also makes it well suited to relating trends in altitude and aspect to climatic controls of glacier mass balance (Evans, 2006).

\section{METHODS}

\section{Inventory extraction}

Within the TRIM database, features coded as glaciers represent exposed ice in the aerial photographs, while icefields represent accumulation zones and some perennial snowpatches. To develop our inventory, we merged glacier and icefield polygons from the 1850 individual TRIM files containing those features to produce an ice-coverage layer for British Columbia using an equal-area projection. Polygons were converted to three-dimensional (3-D) features using the TRIM DEM with a $25 \mathrm{~m}$ grid size. Reported horizontal and vertical accuracies of the data are \pm 10 and $\pm 5 \mathrm{~m}$, respectively (Geographic Data BC, http://ilmbwww. gov.bc.ca/bmgs/pba/trim); however, we observed vertical errors $>50 \mathrm{~m}$ in the accumulation areas of many glaciers (Schiefer and others, 2007).

The number, spatial extent and complexity of ice masses in British Columbia warranted the use of an automated method to delimit individual glaciers. We developed algorithms to divide complex ice masses into flow sheds for individual glaciers and extract morphometric properties from the 3-D polygon coverage (Fig. 1). Potential glacier termini were identified along polygon boundaries where relief exceeds $250 \mathrm{~m}$ from polygon vertices identified as local minima. This relief-based procedure for identifying termini was deemed appropriate for British Columbia because all glaciers are situated in high-relief terrain and are topographyconstrained, at least partially, at mid- to low elevations. The $250 \mathrm{~m}$ relief threshold represents a compromise between lower thresholds that identify multiple termini along undulating glacier toes and higher thresholds that fail to detect smaller glaciers. We used a standard DEM-based algorithm (Jenson and Domingue, 1988) to delimit the contributing drainage basin area for each identified terminus because watershed divides approximate ice-flow divides. The analysis excluded ice bodies $<0.1 \mathrm{~km}^{2}$, to omit small and inconsistently mapped ice- and snowpatches; it also excluded ice that bordered the TRIM mapping extent, as we lacked sufficient data for those regions within Alaska and Alberta.

Following flow-shed delineation, we derived dimensional characteristics for each glacier that included glacier length, area, aspect and centroid coordinate, as well as octile-based measures of glacier altitude, width and number of width segments (Fig. 2). Glacier length was calculated as the maximum surface flow distance down-glacier. Since the length measures are based on the maximum flow path that water would take over the glacier surface, the lengths are longer (by 10-15\%) than equivalent maximum distances taken along typical longitudinal center-line profiles, as surface flow paths are deflected towards lower glacier 


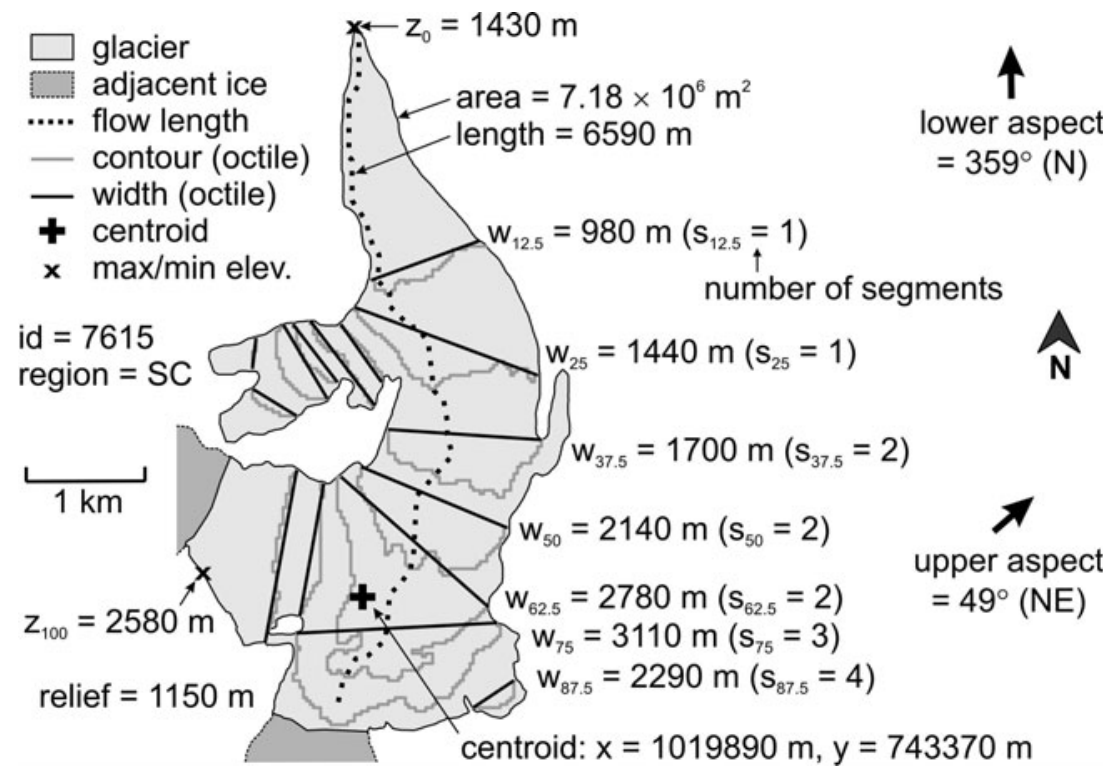

Fig. 2. Sample dimensional characteristics obtained for an unnamed glacier of the southern Coast (SC) Mountains $\left(51^{\circ} 42^{\prime} \mathrm{N}, 125^{\circ} 43^{\prime} \mathrm{W}\right)$. Subscripts indicate the percentile elevation, based on octiles $\left(12.5 \%\right.$ interval), used for glacier width measures (e.g. $w_{25}$ is the total width and $s_{25}$ is the number of segments at the 25th percentile elevation of the glacier).

margins that are typically convex in cross-section. Glacier aspect was obtained for upper and lower glacier areas, based on averaged DEM surface aspects above and below the median glacier altitude, respectively. To include information on surface hypsometry in the inventory, we determined maximum, minimum and percentile altitudes at $12.5 \%$ intervals (octiles) for each glacier area. These altitude octiles, which split glacier area equally, were likewise used to obtain additional information on glacier shape by defining seven different width measures. We calculated widths $(w)$ as straight distances over ice between points where the glacier polygon boundary crossed an octile altitude. The corresponding number of segments $(s)$ indicates the number of contributing ice flows at that altitude (Fig. 2). Parameterization of surface convexity was also considered for the inventory, but DEM artifacts, particularly in accumulation zones, precluded a systematic analysis of surface form.

\section{Morphometric analyses}

We correlated glacier length with other inventory parameters to determine whether length could be used as a predictor variable. Exponential and power-law correlations were employed where appropriate (i.e. one or both of the parameters log-transformed) to account for non-linear relations between these parameters (Dyurgerov and Bahr, 1999). Stratification strategies were explored in examining these relations, including stratification by region and other morphometric parameters. Results were tabulated as Pearson product-moment coefficients $(r)$ for statistically significant $(p<0.05)$ correlations. We used standard linear regression to obtain glacier area from length.

Altitude limits attained by glaciers reflect mass-balance dynamics which are partly explained by regional climate and local topographical influences (Østrem, 1966, 1972; Olyphant, 1985; Evans and Cox, 2005; Evans, 2006). We produced provincial maps of glacier mid-range altitude (average of $z_{0}$ and $z_{100}$, hereafter abbreviated mid-altitude or $z_{\text {mid }}$ ) by spatial interpolation. For our data, mid-altitude is highly correlated with median glacier altitude $(r=0.98$; $p<0.001$ ) which approximates the equilibrium-line altitude (ELA) for some glaciers (Cogley and Mclntyre, 2003; Leonard and Fountain, 2003). The method of universal kriging allowed us to produce a spatially continuous map of glacier mid-altitude for the mountain ranges of British Columbia. Universal kriging is an unbiased, least-squares optimization technique to obtain a trend surface of a nonstationary and spatially correlated regional variate from irregularly distributed observations (Davis, 1986). Spatial correlation structure provides the basis for variate prediction at unmeasured locations in addition to a local estimation of standard error. We assessed interpolation performance by examining the kriging-algorithm fit to the semivariogram, and by comparing predicted mid-altitudes with the observed glacier inventory values (Davis, 1986).

We used the modeling approach of Evans and Cox (2005) to regionally quantify spatial patterns and aspect controls on mid-range glacier altitudes. The models were derived by multiple regression analyses which relate mid-altitude to feature coordinates $(x$ and $y$ ) as well as the cosine and sine of the glacier aspect $(\cos \theta$ and $\sin \theta)$ within a single model. Model coefficients describe spatial trends and aspect bias effects among glacier regions (Evans and Cox, 2005). Coordinate coefficients indicate the rate of mid-altitude change per unit distance in north-south $(\mathrm{N}-\mathrm{S})$ and east-west $(\mathrm{E}-\mathrm{W})$ directions. Aspect cosine and sine coefficients are firstorder Fourier terms that indicate the aspect asymmetry of mid-altitude. The cosine-derived asymmetry is the predicted altitude difference between mid-altitudes of north-facing glaciers and perpendicular- (east- or west-) facing glaciers. Similarly, the sine-derived asymmetry is the predicted difference between east-facing glaciers and those facing north or south. The cosine- and sine-asymmetry coefficients are thus half of the mid-altitude contrast between north- and south- or east- and west-facing glaciers, respectively. We used a similar modeling approach to examine regional trends in minimum glacier altitudes $\left(z_{0}\right)$. The influence of additional morphometric controls on inventoried glacier altitudes was also investigated. 


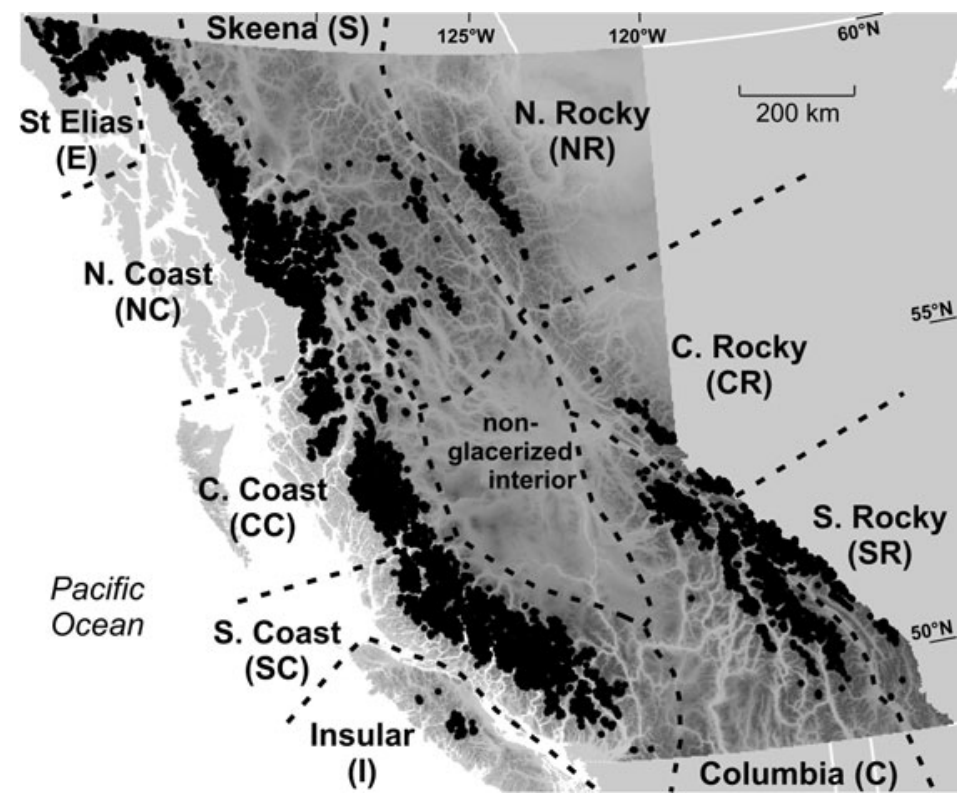

Fig. 3. Spatial distribution of inventory glaciers (black points) and defined glacier regions used for morphometric analyses. Hypsometric shading shows relief and geographic extent of British Columbia. NC and E regions border on Alaska, and SR and CR regions border on Alberta.

\section{RESULTS}

\section{Inventory description}

The flow-shed algorithm defined 12031 glaciers in British Columbia. We subsequently stratified glaciers by mountain system into a total of ten sub-regions, with the Coast and Rocky Mountains being subdivided into northern, central and southern sections at major transverse valleys (Fig. 3). The proportion of cirque and apron glaciers, estimated here as glaciers with a median width exceeding their length, ranges from $4 \%$ in the St Elias Mountains to $42 \%$ in the Insular Mountains. Total glacier area for the resulting inventory is $25008 \mathrm{~km}^{2}$, which represents $82 \%$ of the total ice-cover area mapped by TRIM. The percentage of TRIM ice areas incorporated into the inventory ranges from $68 \%$ to $89 \%$ for individual mountain regions, with the inventory dominated by glaciers smaller than $1 \mathrm{~km}^{2}$ (Table 1 ). The TRIM mapping includes areas of neighboring Alaska and Alberta within a few kilometers of the British Columbia border, resulting in $833 \mathrm{~km}^{2}$ (3.3\%) of the inventoried glacier area falling slightly outside British Columbia.

Mapped ice that was not incorporated into the inventory includes glaciers with an area or relief $<0.1 \mathrm{~km}^{2}$ or $<250 \mathrm{~m}$, respectively, and glaciers that extend beyond the TRIM mapping extent (Fig. 1). Locally comprehensive glacier size and relief distributions for Vancouver Island, Stikine River Basin and the St Elias Mountains, based on mid-20thcentury photography and available through the WGI, indicate that the size- and relief-based exclusions may underestimate total glacier area by $\sim 7 \%$ and the number of glaciers by $\sim 69 \%$ for those regions. These excluded features are dominantly classified as glacierets and snowfields in the

Table 1. British Columbia glacier inventory summary by mountain region

\begin{tabular}{|c|c|c|c|c|c|c|c|c|c|c|}
\hline \multirow[t]{2}{*}{ Region* } & \multirow{2}{*}{$\begin{array}{c}\text { Total glacier } \\
\text { area } \\
\mathrm{km}^{2}\end{array}$} & \multirow{2}{*}{$\begin{array}{c}\% \text { of } \\
\text { TRIM ice }\end{array}$} & \multirow{2}{*}{$\begin{array}{c}\text { Total number } \\
\text { of glaciers }\end{array}$} & \multirow{2}{*}{$\begin{array}{l}\% \text { cirque and } \\
\text { apron glaciers }\end{array}$} & \multicolumn{3}{|c|}{ Number with area exceeding } & \multirow{2}{*}{$\begin{array}{c}\text { Maximum } \\
\text { area } \\
\mathrm{km}^{2}\end{array}$} & \multirow{2}{*}{$\begin{array}{c}\text { Maximum } \\
\text { length } \\
\text { km }\end{array}$} & \multirow{2}{*}{$\begin{array}{c}\text { Maximum } \\
\text { relief } \\
\mathrm{km}\end{array}$} \\
\hline & & & & & $1 \mathrm{~km}^{2}$ & $10 \mathrm{~km}^{2}$ & $100 \mathrm{~km}^{2}$ & & & \\
\hline E & 2928 & 68 & 478 & 4 & 224 & 32 & 5 & 451 & $59^{\ddagger}$ & 2.5 \\
\hline $\mathrm{NC}$ & 8549 & 81 & 2983 & 7 & 1272 & 124 & 14 & 244 & 47 & 3.0 \\
\hline $\mathrm{CC}$ & 1937 & 80 & 1898 & 21 & 633 & 5 & 0 & 19 & 13 & 1.7 \\
\hline SC & 7145 & 89 & 3183 & 17 & 1356 & 88 & 4 & $492^{\dagger}$ & 51 & $3.6 \S$ \\
\hline I & 22 & 77 & 45 & 42 & 4 & 0 & 0 & 2 & 2 & 0.7 \\
\hline S & 618 & 86 & 565 & 19 & 160 & 5 & 0 & 15 & 9 & 1.2 \\
\hline NR & 432 & 87 & 388 & 5 & 127 & 1 & 0 & 24 & 13 & 1.5 \\
\hline CR & 335 & 79 & 218 & 14 & 78 & 5 & 0 & 16 & 9 & 1.7 \\
\hline SR & 1043 & 80 & 650 & 15 & 209 & 19 & 0 & 44 & 14 & 2.2 \\
\hline C & 1998 & 85 & 1623 & 11 & 485 & 19 & 0 & 28 & 13 & 2.1 \\
\hline All regions & 25008 & 82 & 12031 & 13 & 4548 & 298 & 23 & $492^{\dagger}$ & $59^{\ddagger}$ & $3.6^{\S}$ \\
\hline
\end{tabular}

*E: St Elias; NC: northern Coast; CC: central Coast; SC: southern Coast; I: Insular; S: Skeena; NR: northern Rocky; CR: central Rocky; SR: southern Rocky; C: Columbia. ${ }^{\dagger}$ Klinaklini Glacier. ${ }^{\ddagger}$ Tweedsmuir Glacier. ${ }^{\circledR}$ Franklin Glacier. 
WGI database. Incomplete mapping of glacier flow sheds over the Alaska and Alberta borders results in the further exclusion of 185 and $39 \mathrm{~km}^{2}$ of TRIM ice and snow cover from the inventory, respectively.

\section{Length-scaling relations}

Power-law relations (log-linear) best describe the association between glacier length and glacier widths (various measures) and area (Table 2). Strongest correlations were observed in the St Elias and northern Coast Mountains, whereas the correlation between length and width was weakest in the Insular and central Coast Mountains. The strongest correlation in the inventory is between glacier length and area $\left(r=0.905 \pm 0.003 ; p<10^{-9}\right)$. For glacier-width magnitudes and segment counts, correlation strength increased for the measures at greater altitudes $(r=0.751 \pm 0.008$ and $0.556 \pm 0.012$ respectively; $\left.p<10^{-9}\right)$. Average width was not as strongly correlated with length as widths measured at the 75 or 87.5 percentile altitudes. Glacier relief was also well correlated with length $\left(r=0.805 \pm 0.006 ; p<10^{-9}\right)$ using an exponential relation (i.e. semi-log linear).

We examined whether glacier length could be used to predict glacier area more closely by applying additional stratifications to the inventory (Table 3). Regression results change monotonically for glaciers with median altitude segment counts $\left(s_{50}\right)$ increasing or decreasing from three. The length-area scaling for cirque/apron and valley glaciers differs (Fig. 4) and shows some variability among mountain regions. This variability, however, is smaller than that observed when stratifying by $s_{50}$.

\section{Mid-altitude mapping}

Glacier altitudes vary greatly among the mountain regions of British Columbia. Glacier mid-altitudes range from $1543 \mathrm{~m}$ in the Insular Mountains to $2549 \mathrm{~m}$ in the southern Rocky

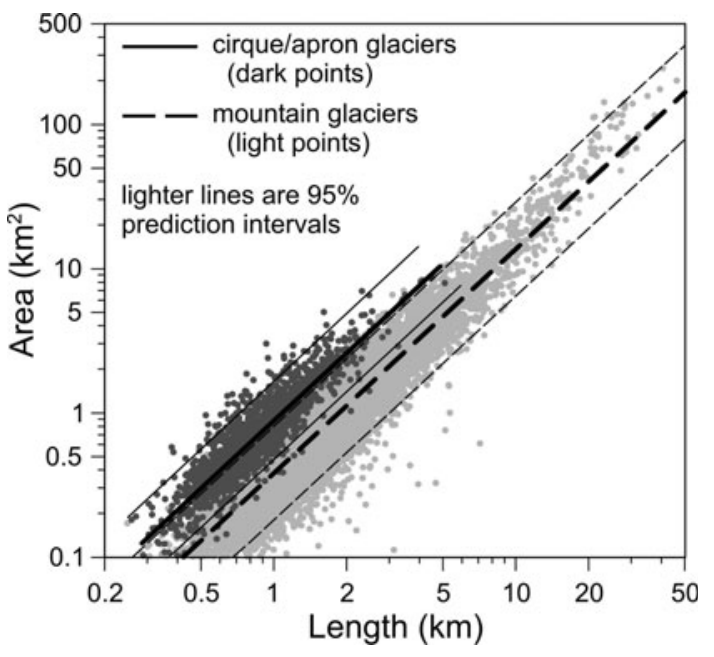

Fig. 4. Length-area scaling of British Columbia glaciers. Cirque and apron glaciers (estimated as features with median altitude width exceeding length) are shown as dark gray points. Lines show powerlaw regression fit with $95 \%$ confidence intervals of prediction.

Mountains (Table 4). Many glaciers in the Coast and St Elias Mountains descend close to sea level. Through trial and error, optimum, kriged glacier mid-altitudes used a spherical model with a $20 \mathrm{~km}$ window radius, which yielded an average standard error of $131 \mathrm{~m}$. A significant 'nugget' effect (Davis, 1986) appears in the semivariogram reflecting shortscale altitude variability among closely clustered glaciers. In particular, significant mid-altitude differences occur between adjacent glaciers on opposing aspects of a mountain crest (i.e. on windward vs leeward slopes). We produced a $20 \mathrm{~km}$ by $20 \mathrm{~km}$ grid of kriged glacier mid-altitude with an associated standard-error map for the mountain ranges of

Table 2. Correlation coefficients $(r)$ between glacier length and other glacier parameters by region using a power-law relation. Correlation with glacier relief expressed as exponential relation

\begin{tabular}{|c|c|c|c|c|c|c|c|c|c|c|c|}
\hline \multirow[t]{2}{*}{ Variable } & \multicolumn{10}{|c|}{ Region } & \multirow[t]{2}{*}{ All regions } \\
\hline & $\mathrm{E}$ & NC & $\mathrm{CC}$ & SC & I & $S$ & NR & CR & $S R$ & $\mathrm{C}$ & \\
\hline Area & 0.958 & 0.936 & 0.812 & 0.904 & 0.566 & 0.873 & 0.896 & 0.894 & 0.909 & 0.901 & 0.905 \\
\hline$s_{12.5}$ & 0.364 & 0.101 & ns & 0.024 & ns & ns & 0.088 & 0.029 & 0.078 & 0.098 & 0.050 \\
\hline$s_{25}$ & 0.485 & 0.333 & 0.031 & 0.228 & ns & ns & 0.148 & 0.145 & 0.210 & 0.204 & 0.226 \\
\hline$s_{37.5}$ & 0.633 & 0.479 & 0.121 & 0.390 & ns & 0.091 & 0.213 & 0.172 & 0.329 & 0.306 & 0.368 \\
\hline$s_{50}$ & 0.678 & 0.555 & 0.236 & 0.475 & ns & 0.264 & 0.323 & 0.478 & 0.403 & 0.417 & 0.467 \\
\hline$s_{62.5}$ & 0.702 & 0.601 & 0.348 & 0.542 & ns & 0.333 & 0.412 & 0.413 & 0.445 & 0.478 & 0.529 \\
\hline$S_{75}$ & 0.704 & 0.627 & 0.355 & 0.564 & ns & 0.407 & 0.428 & 0.526 & 0.570 & 0.476 & 0.557 \\
\hline$s_{87.5}$ & 0.736 & 0.613 & 0.359 & 0.564 & 0.311 & 0.440 & 0.419 & 0.489 & 0.538 & 0.473 & 0.556 \\
\hline Mean $s$ & 0.853 & 0.791 & 0.479 & 0.714 & $\mathrm{~ns}$ & 0.633 & 0.675 & 0.676 & 0.711 & 0.714 & 0.609 \\
\hline$w_{12.5}$ & 0.662 & 0.584 & 0.293 & 0.480 & ns & 0.485 & 0.533 & 0.545 & 0.582 & 0.565 & 0.498 \\
\hline$w_{25}$ & 0.705 & 0.628 & 0.277 & 0.529 & ns & 0.501 & 0.560 & 0.554 & 0.578 & 0.584 & 0.531 \\
\hline$w_{37.5}$ & 0.774 & 0.681 & 0.311 & 0.594 & ns & 0.522 & 0.572 & 0.599 & 0.614 & 0.611 & 0.585 \\
\hline$W_{50}$ & 0.811 & 0.728 & 0.367 & 0.663 & ns & 0.558 & 0.602 & 0.626 & 0.645 & 0.651 & 0.641 \\
\hline$w_{62.5}$ & 0.839 & 0.776 & 0.478 & 0.713 & ns & 0.621 & 0.631 & 0.634 & 0.692 & 0.695 & 0.698 \\
\hline$w_{75}$ & 0.853 & 0.800 & 0.549 & 0.744 & 0.360 & 0.638 & 0.662 & 0.670 & 0.708 & 0.712 & 0.730 \\
\hline$w_{87.5}$ & 0.861 & 0.805 & 0.599 & 0.765 & 0.297 & 0.703 & 0.663 & 0.677 & 0.723 & 0.725 & 0.751 \\
\hline Mean $w$ & 0.853 & 0.791 & 0.479 & 0.714 & ns & 0.633 & 0.675 & 0.676 & 0.711 & 0.714 & 0.708 \\
\hline Relief* & 0.849 & 0.833 & 0.741 & 0.815 & 0.593 & 0.749 & 0.700 & 0.738 & 0.795 & 0.767 & 0.805 \\
\hline
\end{tabular}

Notes: E: St Elias; NC: northern Coast; CC: central Coast; SC: southern Coast; I: Insular; S: Skeena; NR: northern Rocky; CR: central Rocky; SR: southern Rocky; C: Columbia. ns indicates that correlation is not significant $(p>0.05)$.

*Exponential relation (semi-log) coefficient of correlation given. 

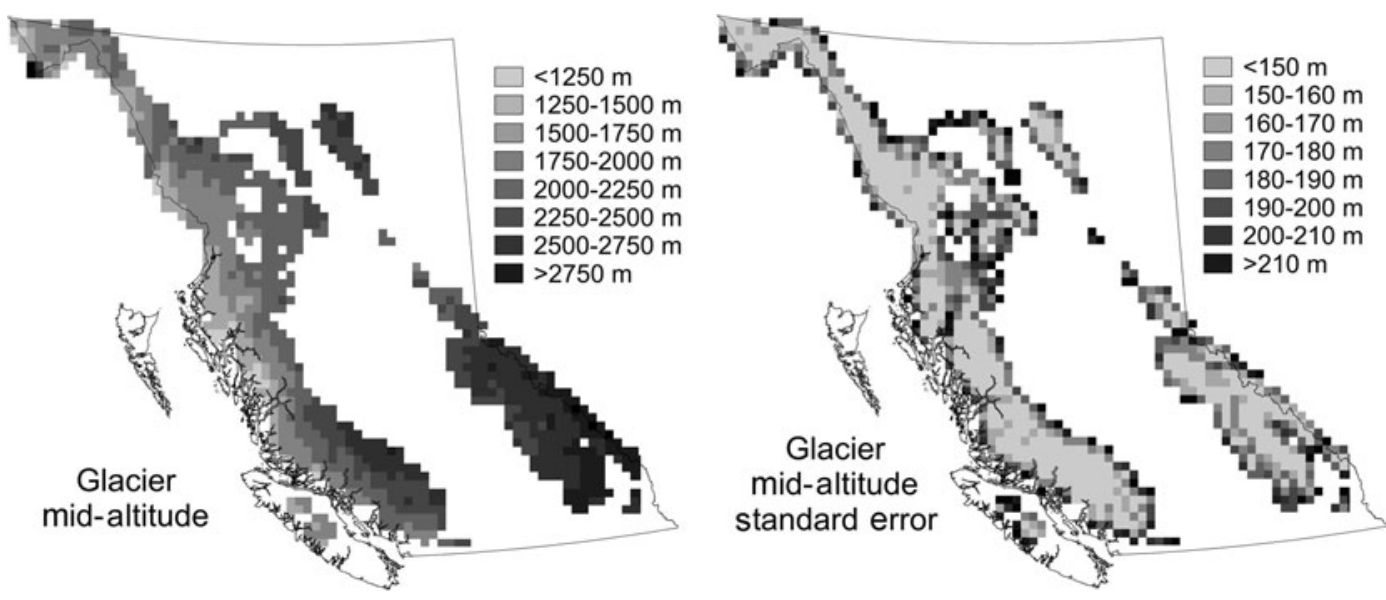

Fig. 5. Map of glacier mid-altitudes and standard errors interpolated by universal kriging on a $20 \mathrm{~km}$ by $20 \mathrm{~km}$ lattice for glacierized regions of British Columbia.

British Columbia (Fig. 5). The dominating spatial trend is that of increasing glacier altitudes for increasingly continental mountains to the northwest of the Pacific coast, with steeper altitude gradients occurring in the coastal ranges. A lesser effect of decreasing altitudes is observed with increasing latitude along the northwest-trending coastal and interior ranges. Glacier mid-altitudes approach $1000 \mathrm{~m}$ on locally exposed, windward glaciers of the Coast Mountains and $3000 \mathrm{~m}$ along the continental divide of the Rocky Mountains and locally in the Fairweather Range of northwestern British Columbia.

\section{Altitude-aspect trends}

Mean vector directions of glaciers indicate an aspect tendency to the NNE with azimuths ranging from $7^{\circ}$ to $38^{\circ}$ (Table 4; Fig. 6). Vector distributions are approximately unimodal, with vector strengths (an inverse measure of vector dispersion $=$ resultant length/total length) ranging from $32 \%$ to $81 \%$. Slightly more eastward aspects were observed for the interior regions, particularly the southcentral Rocky and Columbia Mountains.
Modeling of glacier mid-altitudes $\left(z_{\mathrm{mid}}\right)$ indicates small $\mathrm{N}-\mathrm{S}$ asymmetries in the northern Rocky, Skeena and Columbia Mountains of 58, 66 and $92 \mathrm{~m}$ (lower northward), respectively, and a greatest asymmetry of $150 \mathrm{~m}$ in the southern Coast Mountains (Table 4). Lower-magnitude E-W asymmetries (all $<100 \mathrm{~m}$, lower eastward) were observed, especially for the Coast Mountains regions where E-W asymmetries were less than half those for the $\mathrm{N}-\mathrm{S}$ direction. Non-significant asymmetries were obtained for the Insular (both directions), St Elias ( $\mathrm{N}-\mathrm{S}$ contrast) and Skeena (E-W contrast) Mountain regressions. Upper aspects (measured above glacier median altitude) explain altitude trends better than the use of lower or average glacier aspects. In most regions, we observed a northward and eastward increase in the median altitude of glaciers of $1-5 \mathrm{~m} \mathrm{~km}^{-1}$. Additional morphometric parameters did not improve the prediction of median glacier altitude. Terminus-altitude $\left(z_{0}\right)$ modeling indicates strong altitude covariance with direction and position that accords with the results of the mid-altitude prediction. We also investigated the use of a shape index $\left(w_{87.5} / w_{12.5}\right)$ to account for the differences in the width of

Table 3. Power-law regression between glacier length $(L(\mathrm{~m}))$ and area $\left(A\left(\mathrm{~m}^{2}\right)\right): A=a L^{b}$

Glaciers included in regression

A
Regression model summary

$b \quad r^{2}$

$r^{2}-d$
0.819

0.706

0.783

0.805

0.857

0.860

0.888

0.907

0.937

0.938

0.796

0.824

0.793

0.798

0.795

0.900 df

12029

6895

2811

1133

450

215

142

80

43

244

6109

781

4262

1845

589

190
$2.336 \pm 0.233$

$2.159 \pm 0.269$
$1.646 \pm 0.034$

$1.658 \pm 0.040$

Notes: All relations significant at $p<10^{-9}$; uncertainty limits represent one standard error. df is degrees of freedom. 
the accumulation and ablation zones in the terminus altitude model (Table 4). For each greater multiple, $w_{87.5}$ (upper glacier width) was relative to $w_{12.5}$ (lower glacier width); altitudes of glacier termini were lower by $61-117 \mathrm{~m}$.

\section{DISCUSSION}

The 12031 inventoried glaciers represent contiguous glacier features that exceed $0.1 \mathrm{~km}^{2}$ in area and $250 \mathrm{~m}$ in relief within British Columbia (Table 1; Fig. 3). The total area of inventoried glaciers in the St Elias Mountains is low relative to the total area of glaciers mapped in TRIM because many glaciers flowing from or into neighboring Alaska are not part of this inventory. The inventoried area is similarly low for the Insular Mountains because most small cirque and apron glaciers in that region fall below the defined minimum area and relief thresholds. Errors in dimensional characteristics of the glaciers due to photogrammetric precision $( \pm 10 \mathrm{~m}$ horizontal, $\pm 5 \mathrm{~m}$ vertical) are probably minimal given the conservative criteria for minimum glacier size we have adopted. Nevertheless, gross errors in glacier identification can be appreciable in some mountain ranges. We observed that debris-covered ice was inconsistently mapped by airphotograph interpreters, with many rock glaciers being unmapped and lower glacier margins being occasionally delineated along exposed ice and debris-covered ice boundaries. Additional errors occur at upper glacier limits in highly rugged and shadowed terrain. The use of orthorectified satellite imagery reveals that, overall, these interpretative errors are probably $\sim 2 \%$ (Bolch and others, 2008). Vertical errors have also been observed to exceed specifications by up to a factor of ten in some high-elevation areas due to low photographic contrast over snow cover (Schiefer and others, 2007).

Glacier length is well correlated with most other inventory parameters using a power-law relation (Table 2). This indicates that length can be used to reasonably approximate many morphometric parameters. The correlation between area and relief is better represented by a logarithmic relation $\left(r=0.805\right.$ overall; $\left.p<10^{-9}\right)$. The

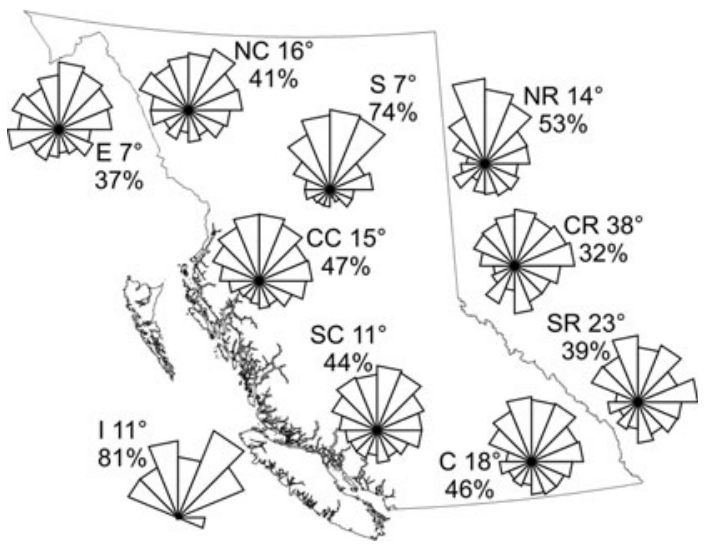

Fig. 6. Rose diagrams of regional glacier aspects (upper glacier areas). Text provided for each rose indicates region, vector mean direction and vector strength.

length-area correlation is especially strong $(r=0.905$ overall; $p<10^{-9}$ ), although this is marginally weaker than the length-area relation reported for a smaller, global dataset of monitored glaciers (Dyurgerov and Bahr, 1999). In our inventory, length and area co-vary least for mountain regions that contain a high proportion of cirque and apron glaciers, such as the Insular and central Coast Mountains. We suspect that this arises from the greater variability of morphometry for those glacier types. For example, $>10 \%$ of the inventoried cirque/apron glaciers are twice as wide as they are long. In the case of the Insular Mountains, weaker correlations would be expected because of the low range of glacier sizes; however, increased variability in morphometric parameters is additionally observed for smaller glaciers (Fig. 4). The strength of the length-width relation increases for glacier width measures up-valley (up to 0.751 overall; $p<10^{-9}$ ). Widths measured at high glacier altitudes may better reflect the size of the accumulation area which may be a more important control on glacier length potential than lower-altitude glacier widths.

Table 4. Elevation and aspect trends in the glacier inventory for British Columbia. The mid-altitude $\left(z_{\text {mid }}\right)$ regression model is of the form


$b_{3} x+b_{4} y+b_{5} w_{87.5} / w_{12.5}$

\begin{tabular}{|c|c|c|c|c|c|c|c|c|c|c|c|c|c|c|}
\hline \multirow[t]{2}{*}{ Region* } & \multicolumn{3}{|c|}{ Summary data } & \multicolumn{5}{|c|}{ Mid-elevation regression model } & \multicolumn{6}{|c|}{ Minimum-elevation regression model } \\
\hline & $\begin{array}{c}\text { Average } \\
Z_{\text {mid }}\end{array}$ & $\begin{array}{l}\text { Minimum } \\
\text { elevation }\end{array}$ & Aspect $^{\dagger}$ & $b_{1}$ & $b_{2}$ & $b_{3}$ & $b_{4}$ & $R^{2}$ & $b_{1}$ & $b_{2}$ & $b_{3}$ & $b_{4}$ & $b_{5}$ & $R^{2}$ \\
\hline $\mathrm{E}$ & 1579 & 171 & 7 & ns & -91 & 3 & $\mathrm{~ns}$ & 0.14 & ns & -108 & 4 & 1 & -117 & 0.41 \\
\hline $\mathrm{NC}$ & 1666 & $5^{\ddagger}$ & 16 & -106 & -44 & 4 & 3 & 0.33 & -102 & -55 & 5 & 3 & -110 & 0.44 \\
\hline $\mathrm{CC}$ & 1577 & 351 & 15 & -107 & -47 & 5 & 3 & 0.54 & -126 & -58 & 5 & 3 & -83 & 0.51 \\
\hline SC & 2023 & 148 & 11 & -150 & -27 & 4 & 5 & 0.62 & -138 & -22 & 4 & 4 & -108 & 0.58 \\
\hline I & 1543 & 968 & 11 & $\mathrm{~ns}$ & $\mathrm{~ns}$ & 5 & 5 & 0.31 & ns & ns & 6 & 5 & ns & 0.36 \\
\hline $\mathrm{S}$ & 1909 & 1029 & 7 & -66 & $\mathrm{~ns}$ & 1 & 1 & 0.55 & -40 & -22 & 1 & 1 & -61 & 0.52 \\
\hline NR & 2218 & 1460 & 14 & -58 & -27 & 3 & 2 & 0.20 & -65 & ns & 3 & 2 & -62 & 0.22 \\
\hline CR & 2222 & 1168 & 38 & -105 & -82 & $\mathrm{~ns}$ & 3 & 0.65 & -128 & -65 & 2 & ns & -73 & 0.54 \\
\hline SR & 2549 & 1106 & 23 & -107 & -62 & 4 & 3 & 0.28 & -57 & -35 & 3 & 2 & -98 & 0.28 \\
\hline C & 2397 & 1206 & 18 & -92 & -57 & 2 & 2 & 0.38 & -91 & -44 & 2 & 1 & -75 & 0.31 \\
\hline
\end{tabular}

Note: ns indicates that correlation is not significant $(p>0.05)$.

*E: St Elias; NC: northern Coast; CC: central Coast; SC: southern Coast; I: Insular; S: Skeena; NR: northern Rocky; CR: central Rocky; SR: southern Rocky; C: Columbia. ${ }^{\dagger}$ Vector mean direction for upper glacier area (above median altitude). ${ }^{\ddagger}$ Grand Pacific Glacier. 


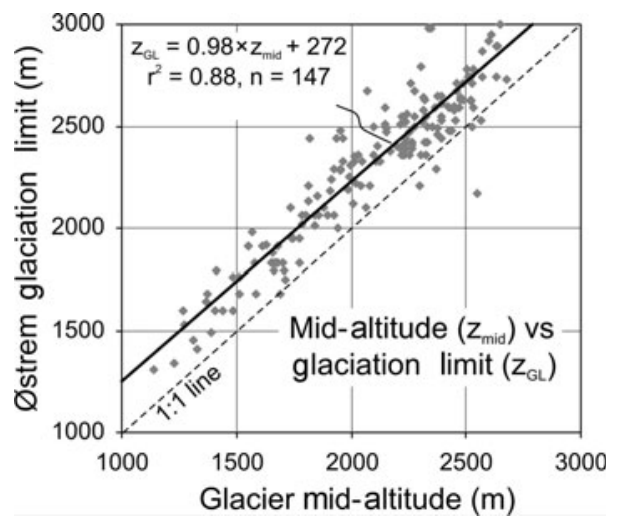

Fig. 7. Comparison of glacier mid-altitudes from this study and glaciation limit altitudes derived by Østrem (1966) for 1:50000 topographic sheet areas for southern British Columbia.

The ability to predict glacier area from length is valuable because former lengths can often be obtained from end moraine positions. Glaciers in British Columbia, for example, constructed prominent moraines at their maximum Holocene extent during the 18th and 19th centuries (Ryder and Thomson, 1986; Osborn and Luckman, 1988). Variability in the length-area relation is considerable, generally exceeding half an order of magnitude (Fig. 4). We observed some interpreter errors, such as the exclusion of debriscovered ice and inclusion of large snowpatches, which explain some of the outliers in our data. Regression coefficients vary for the length-area power relation when glaciers are stratified by the number of ice segments at the median altitude (Table 3). Both coefficients exhibit local extremes for $s_{50}=3$. We speculate that this change in scaling behavior may be associated with changing flow dynamics of cirque and apron glaciers which have low segment counts. The length-width scaling of cirque and apron glaciers is notably different from that of valley glaciers (Fig. 4). The amount of variance explained and the slope of the scaling relation increases with segment counts up to $s_{50}=9$. Since $s_{50}$ is a measure of the number of separate accumulation zones per glacier, the increasing strength of the length-area scaling is likely to be caused by the greater potential of down-valley mass transfer by glaciers with a greater number of up-valley accumulation basins. The presence of relatively insignificant nunataks adds noise to this measure; however, we still find it to be an effective index of contributing accumulation zones. Best scaling relations for estimating glacier area from length are obtained by stratifying glaciers by median altitude segment counts rather than by glacier type or regional stratification. The 10$15 \%$ underestimation of glacier lengths obtained by our methods introduces some additional variability which can affect the transferability of the predictive relations. We observed this to be a largely scale-independent bias, indicating that the documented scaling patterns are robust. Areas tend to be underestimated for the largest glaciers in British Columbia $\left(>50 \mathrm{~km}^{2}\right.$; see Fig. 4), reflecting the reduced topographic confinement of large ice caps.

Glacier mid-altitudes increase eastward, reflecting the increasingly continental environments of the cordillera's eastern ranges (Table 4; Fig. 5), closely following glaciation limits previously described for western Canada by Østrem (1966, 1972). Glaciation limits are threshold altitudes which mountain summits must exceed for glacier formation. This altitude limit is a useful index of glacier ELA, although midaltitude will be higher since it is based on summit heights (Østrem, 1966; Cogley and McIntyre, 2003). A strong, positive relation exists between glacier mid-altitudes and glaciation limits obtained from 1:50000 topographic maps $(28 \mathrm{~km} \times 35 \mathrm{~km}$ units), but with mid-altitudes lower by $\sim 270 \mathrm{~m}$ (Fig. 7). Mid-altitude, therefore, is also likely to be a good index of ELA, but with mid-altitude still being higher since toe-to-headwall altitude ratios of $0.35-0.40$ are typically applied for ELA estimation (Nesje, 1992). Both of these potential ELA indices mirror a strong, inverse relation with winter precipitation patterns of British Columbia (Østrem, 1966, 1972). Variability in glacier mid-altitude is greatest in the coastal ranges, with localized patterns generally corresponding to large-scale topographic controls (Østrem, 1972) (Fig. 5). Areas with depressed mid-altitudes correspond to subdued coastal topographies which can promote the inland movement of maritime air masses (e.g. Tatshenshini River valley of the St Elias Mountains; Queen Charlotte Sound and the major fiords of the central coast; and the exposed west slopes of Vancouver Island). Areas with elevated mid-altitudes correspond to strong rain shadows that are likely to be set up in the lee of highsummit regions (e.g. Fairweather Mountain-Fairweather Ranges, Mount Ratz-Border Ranges and Mount Waddington-Pacific Ranges). Aspect-associated controls may account for much of the smaller-scale variability, reflected by the interpolated standard errors of glacier mid-altitude which exceed $100 \mathrm{~m}$ in all regions.

Favored glacier azimuths, ranging between 7 and $38^{\circ}$ regionally (Table 4; Fig. 6), are explained by the incidence and shading of solar radiation causing the northward-aspect tendency, and secondary effects of wind and diurnal climate causing the eastward tendency (Evans, 2006). Modeling of glacier altitudes similarly shows these aspect-associated trends; although, unlike those reported for many other regions (Evans and Cox, 2005), here the directional contrasts do not exceed an order of magnitude. In modeling midaltitudes for interior British Columbia glaciers, for example, the $\mathrm{E}-\mathrm{W}$ asymmetries exceed half the $\mathrm{N}-\mathrm{S}$ asymmetries. The greater eastward bias in the Rockies may relate to structural control in that highly lineated (north-northwest-trending) mountain belt. An easterly favored aspect may also be attributed to enhanced wind loading of snow on east-facing glaciers (Brown, 2003). Continental climates typify these ranges, where low-density snowfall is redistributed by strong westerly winds of the mid-troposphere which are not disrupted by the coastal ranges (Shea and others, 2004; US National Centers for Environmental Prediction re-analysis data, http://www.cdc.noaa.gov). This hypothesis differs from previous research where wind was purported to elevate $\mathrm{E}-\mathrm{W}$ asymmetries in coastal mountains, caused by greater wind magnitudes, and because $\mathrm{N}-\mathrm{S}$ asymmetries can be more subdued, due to generally cloudier conditions (Evans and Cox, 2005). In the southern Coast Mountains, south and south-southwest winds dominate during and immediately following snowfall events, thus reinforcing the $\mathrm{N}-\mathrm{S}$ asymmetry and potentially compensating for any attenuated solar influences (Evans, 1990). Within the southern Coast Mountains, Evans (1990) observed similar northward azimuths between coastal and landward subregions, but with weaker vector strengths in more coastal settings. Regional variations in the $\mathrm{N}-\mathrm{S}$ asymmetries may be associated with 
glacier gradient differences since solar-radiation contrasts are greater for steep terrain due to increased shading (Evans and Cox, 2005). Maximum N-S asymmetry for glacier midaltitudes in British Columbia was $150 \mathrm{~m}$, corresponding to a $300 \mathrm{~m}$ altitude contrast between north and south slopes, observed for the steep terrain and high glacier gradients of the southern Coast Mountains. Relatively low N-S asymmetries $(<100 \mathrm{~m})$ occur in regions with lowest glacier gradients, including the northern Rocky, Skeena and Columbia Mountains. For modeling of glacier altitudes, we obtained improved results using upper glacier aspects. This is an indication that aspect-associated controls are most evident for accumulation areas where the generation of surplus snow permits glacier formation.

The inclusion of a shape index $\left(w_{87.5} / w_{12.5}\right)$ for the modeling of glacier terminus altitudes was necessary to explain similar amounts of altitude variance obtained in the modeling of glacier mid-altitudes (Table 4). In many cases, the shape-index variable was more significant than the aspect parameters in the model. Glaciers constrained by topography in their ablation zones with a broad upper accumulation area would transport more ice to lower elevations than glaciers with a more uniform distribution of widths up-valley. Terminus altitudes were lower by $61-$ $117 \mathrm{~m}$ for each multiple that upper glacier widths were wider than lower glacier widths. A consistent maritime-tocontinental influence on glacier mid- and terminus altitudes is also observed in British Columbia at rates of $1-6 \mathrm{~m} \mathrm{~km}^{-1}$ northward and eastward. These trends parallel glaciation limits for western Canada, with steeper altitude gradients associated with increasingly maritime regions which have steeper orographic gradients (Østrem, 1966, 1972).

\section{CONCLUSIONS}

We have developed a glacier inventory for British Columbia, a region that represents a large proportion of the North American Cordillera which is largely absent from current inventories, including the WGI and the Global Land Ice Measurements from Space (GLIMS) glacier database. The automated procedures used for glacier delimitation utilized standard Geographic Information System (GIS)-based algorithms and existing topographic datasets for the province. Where similar data exist, our methods could be applied to other glacierized mountain regions for the rapid development and expansion of regional and global glacier inventories. Algorithm thresholds used for glacier delineation may require modification, however, to reflect the specific size and relief characteristics of glaciers for a given region. The objectively derived and high-precision potential of glacier attributes obtained in the inventories makes the extracted databases well suited for a range of morphometric analyses. Difficulties expressed with the WGI, currently the largest global glacier inventory available, include the subjective nature of glacier-width measurements which can obscure geometric scaling relations (Bahr, 1997), and the low precision of aspect measurements which are only provided as eight-point headings (Evans, 2006). Although the GLIMS glacier database (Bishop and others, 2004) is promising, it has been slow in developing global coverage (Paul and others, 2007).

Morphometric analyses performed with the British Columbia glacier inventory yielded similar results to those reported from studies of other global and regional glacier databases (e.g. Østrem, 1966, 1972; Dyurgerov and Bahr, 1999; Evans and Cox, 2005). Some differences of note include:

Glacier length-area correlations are marginally lower than those reported for monitored glaciers by Dyurgerov and Bahr (1999); however, improved relations can be obtained for valley glaciers by stratifying features according to the number of up-valley accumulation zones.

Glacier mid-altitudes are strongly correlated with British Columbia glaciation limits (Østrem, 1966, 1972) and may represent a more easily generated index of large-scale orographic and continental controls on regional ELAs.

$\mathrm{E}-\mathrm{W}$ aspect asymmetries are greater for the interior ranges than the Coast Mountains, which is opposite to the general coastal-to-inland global trend reported by Evans and Cox (2005). This trend is especially strong in southern British Columbia and may reflect enhanced wind-loading effects to east-facing slopes inland.

Terminus altitudes of glaciers may be predicted as effectively as mid-altitudes using the aspect- and position-based modeling approach of Evans and Cox (2005), with the addition of a shape index describing the width ratio between accumulation and ablation areas. This simple index reflects the potential for ice mass transfer to lower elevations down-valley.

Further advances in explaining observed variability in large glacier inventories will improve our ability to make inferences about climatic forcings and morphometric characteristics of past and present glaciers. The comprehensive nature of this inventory may also make it useful for the selection of representative glacier features, as well as for large-scale visualization and modeling, in future glaciological research.

\section{ACKNOWLEDGEMENTS}

This study was supported by the Western Canadian Cryospheric Network, funded by the Canadian Foundation for Climate and Atmospheric Sciences. We thank the British Columbian Government for providing the provincial TRIM planimetric and DEM data. We greatly appreciate thorough reviews by G. Cogley and I. Evans which significantly improved the quality of the manuscript.

\section{REFERENCES}

Bahr, D.B. 1997. Width and length scaling of glaciers. J. Glaciol. 43(145), 557-562.

Bahr, D.B., M.F. Meier and S.D. Peckham. 1997. The physical basis of glacier volume-area scaling. J. Geophys. Res., 102(B9), 20,355-20,362.

Barnett, T.P., J.C. Adam and D.P. Lettenmaier. 2005. Potential impacts of a warming climate on water availability in snowdominated regions. Nature, 438(7066), 303-309.

Barry, R.G. 2006. The status of research on glaciers and global glacier recession: a review. Progr. Phys. Geogr., 30(3), 285-306.

Bishop, M.P. and 16 others. 2004. Global Land Ice Measurements from Space (GLIMS): remote sensing and GIS investigations of the Earth's cryosphere. Geocarto Int., 19(2), 57-84.

Bolch, T., B. Menounos and R. Wheate. 2008. Remotely-sensed western Canadian glacier inventory 1985-2005 and regional glacier recession rates. Geophys. Res. Abstr. 10, 10403. (16077962/gra/EGU2008-A-10403.) 
Brown, R.D., B. Brasnett and D. Robinson. 2003. Gridded North American monthly snow depth and snow water equivalent for GCM evaluation. Atmos.-Ocean, 41(1), 1-14.

Clague, J.J. and S.G. Evans. 2000. A review of catastrophic drainage of moraine-dammed lakes in British Columbia. Quat. Sci. Rev., 19(17-18), 1763-1783.

Cogley, J.G. and M.S. Mclntyre. 2003. Hess altitudes and other morphological estimators of glacier equilibrium lines. Arct. Antarct. Alp. Res., 35(4), 482-488.

Davis, J.C. 1986. Statistics and data analysis in geology. Second edition. New York, etc., John Wiley and Sons.

Dyurgerov, M.B. and D.B. Bahr. 1999. Correlations between glacier properties: finding appropriate parameters for global glacier monitoring. J. Glaciol., 45(149), 9-16.

Evans, I.S. 1990. Climatic effects on glacier distribution across the southern Coast Mountains, B.C., Canada. Ann. Glaciol., 14, 58-64.

Evans, I.S. 2006. Local aspect asymmetry of mountain glaciation: a global survey of consistency of favoured directions for glacier numbers and altitudes. Geomorphology, 73(1-2), 166-184.

Evans, I.S. and N.J. Cox. 2005. Global variations of local asymmetry in glacier altitude: separation of north-south and eastwest components. J. Glaciol., 51(174), 469-482.

Haeberli, W., H. Bösch, K. Scherler, G. Østrem and C.C. Wallén. 1989. World glacier inventory: status 1988. Wallingford, Oxon, IAHS Press; Nairobi, GEMS-UNEP; Paris, UNESCO.

Hoelzle, M., T. Chinn, D. Stumm, F. Paul, M. Zemp and W. Haeberli. 2007. The application of glacier inventory data for estimating past climate change effects on mountain glaciers: a comparison between the European Alps and the Southern Alps of New Zealand. Global Planet. Change, 56(1-2), 69-82.

Holm, K., M. Bovis and M. Jakob. 2004. The landslide response of alpine basins to post-Little Ice Age glacial thinning and retreat in southwestern British Columbia. Geomorphology, 57(3-4), 201-216.

Jenson, S.K. and J.O. Domingue. 1988. Extracting topographic structure from digital elevation data for geographic information system analysis. Photogramm. Eng. Remote Sens., 54(11), $1593-1600$.

Jóhannesson, T., C.F. Raymond and E.D. Waddington. 1989. A simple method for determining the response time of glaciers. In Oerlemans, J., ed. Glacier fluctuations and climatic change. Dordrecht, etc., Kluwer Academic Publishers, 343-352.

Lemke, P. and 10 others. 2007. Observations: changes in snow, ice and frozen ground. In Solomon, S. and 7 others, eds. Climate change 2007: the physical science basis. Contribution of Working Group I to the Fourth Assessment Report of the Intergovernmental Panel on Climate Change. Cambridge, etc., Cambridge University Press.

Leonard, K.C. and A.G. Fountain. 2003. Map-based methods for estimating glacier equilibrium-line altitudes. J. Glaciol., 49(166), 329-336.
Nesje, A. 1992. Topographical effects on the equilibrium-line altitude on glaciers. GeoJournal, 27(4), 383-391.

Nye, J.F. 1965. The flow of a glacier in a channel of rectangular, elliptic or parabolic cross-section. J. Glaciol., 5(41), 661-690.

Oerlemans, J., M. Dyurgerov and R.S.W. van de Wal. 2007. Reconstructing the glacier contribution to sea-level rise back to 1850. Cryosphere, 1(1), 59-65.

Olyphant, G.A. 1985. Topoclimate and the distribution of Neoglacial facies in the Indian Peaks section of the Front Range, Colorado, USA. Arct. Alp. Res., 17(1), 69-78.

Ommanney, C.S.L. 1971. The Canadian glacier inventory. In Glaciers, Proceedings of Workshop Seminar 1970, 24-25 September 1970, Vancouver, B.C. Ottawa, Ont., Canadian National Committee for the International Hydrological Decade, $23-30$.

Ommanney, C.S.L. 2002. History of glacier investigations in Canada. In Williams, R.S., Jr and J.G. Ferrigno, eds. Satellite image atlas of glaciers of the world. US Geol. Surv. Prof. Pap. 1386-J, J27-J82.

Osborn, G. and B.H. Luckman. 1988. Holocene glacier fluctuations in the Canadian Cordillera (Alberta and British Columbia). Quat. Sci. Rev., 7(2), 115-128.

Østrem, G. 1966. The height of the glaciation limit in southern British Columbia and Alberta. Geogr. Ann., 48A(3), 126-138.

Østrem, G. 1972. Height of the glaciation level in northern British Columbia and southeastern Alaska. Geogr. Ann., 54A(2), 76-84.

Paterson, W.S.B. 1972. Laurentide ice sheet: estimated volumes during Late Wisconsin. Rev. Geophys. Space Phys., 10(4), 885-917.

Paul, F., A. Kääb and W. Haeberli. 2007. Recent glacier changes in the Alps observed from satellite: consequences for future monitoring strategies. Global Planet. Change, 56(1-2), 111-122.

Raup, B., A. Racoviteanu, S.J.S. Khalsa, C. Helm, R. Armstrong and Y. Arnaud. 2007. The GLIMS geospatial glacier database: a new tool for studying glacier change. Global Planet. Change, 56(1-2), 101-110.

Ryder, J.M. and B. Thomson. 1986. Neoglaciation in the southern Coast Mountains of British Columbia: chronology prior to the Late Neoglacial maximum. Can. J. Earth Sci., 23(3), 273-287.

Schiefer, E., B. Menounos and R. Wheate. 2007. Recent volume loss of British Columbian glaciers, Canada. Geophys. Res. Lett., 34(16), L16503. (10.1029/2007GL030780.)

Shea, J.M., S.J. Marshall and J.M. Livingston. 2004. Glacier distributions and climate in the Canadian Rockies. Arct. Antarct. Alp. Res., 36(2), 272-279.

Stahl, K. and D. Moore. 2006. Influence of watershed glacier coverage on summer streamflow in British Columbia, Canada. Water Resour. Res., 42(6), W06201. (10.1029/2006WR005022.)

Williams, R.S., Jr and J.G. Ferrigno, eds. 2002. Satellite image atlas of glaciers of the world - North America. US Geol. Surv. Prof. Pap. 1386-J. 